Research

\title{
Ovarian steroids regulate tachykinin and tachykinin receptor gene expression in the mouse uterus Francisco M Pinto ${ }^{1}$, C Oscar Pintado², Jocelyn N Pennefather ${ }^{3}$, Eva Patak ${ }^{4}$ and Luz Candenas*1
}

Address: ${ }^{1}$ Instituto de Investigaciones Químicas, CSIC, Avda. Americo Vespucio 49, 41092, Sevilla, Spain, ${ }^{2}$ Centro de Producción y Experimentación Animal, Universidad de Sevilla, Sevilla, Spain, ${ }^{3}$ Department of Pharmaceutical Biology, Monash University, Parkville, Victoria 3052, Australia and ${ }^{4}$ Department of Anaesthetics, Royal Women's Hospital, Carlton, Victoria 3051, Australia

Email: Francisco M Pinto - Francisco.pinto@iiq.csic.es; C Oscar Pintado - oscarpintado@us.es; Jocelyn N Pennefather - jocelyn.oneil@pharm.monash.edu.au; Eva Patak - Eva.Patak@med.monash.edu.au; Luz Candenas* - luzcandenas@iiq.csic.es

* Corresponding author

Published: 23 July 2009

Reproductive Biology and Endocrinology 2009, 7:77 doi:10.1186/1477-7827-7-77

This article is available from: http://www.rbej.com/content/7/1/77

(C) 2009 Pinto et al; licensee BioMed Central Ltd.

This is an Open Access article distributed under the terms of the Creative Commons Attribution License (http://creativecommons.org/licenses/by/2.0), which permits unrestricted use, distribution, and reproduction in any medium, provided the original work is properly cited.
Received: 6 May 2009

Accepted: 23 July 2009

\begin{abstract}
Background: In the mouse uterus, pregnancy is accompanied by changes in tachykinin and tachykinin receptor gene expression and in the uterotonic effects of endogenous tachykinins. In this study we have investigated whether changes in tachykinin expression and responses are a result of changes in ovarian steroid levels.

Methods: We quantified the mRNAs of tachykinins and tachykinin receptors in uteri from ovariectomized mice and studied their regulation in response to estrogen and progesterone using real-time quantitative RT-PCR. Early $(3 \mathrm{~h})$ and late $(24 \mathrm{~h})$ responses to estrogen were evaluated and the participation of the estrogen receptors (ER), ERalpha and ERbeta, was analyzed by treating mice with propylpyrazole triol, a selective ERalpha agonist, or diarylpropionitrile, a selective agonist of ERbeta.

Results: All genes encoding tachykinins (Tacl, Tac2 and Tac4) and tachykinin receptors (Tacrl, Tacr2 and Tacr3) were expressed in uteri from ovariectomized mice. Estrogen increased Tacl and Tacr I mRNA after $3 \mathrm{~h}$ and decreased Tacl and Tac4 expression after $24 \mathrm{~h}$. Tac2 and Tacr3 mRNA levels were decreased by estrogen at both 3 and $24 \mathrm{~h}$. Most effects of estrogen were also observed in animals treated with propylpyrazole triol. Progesterone treatment increased the levels of Tac 2.

Conclusion: These results show that the expression of tachykinins and their receptors in the mouse uterus is tightly and differentially regulated by ovarian steroids. Estrogen effects are mainly mediated by ERalpha supporting an essential role for this estrogen receptor in the regulation of the tachykinergic system in the mouse uterus.
\end{abstract}

\section{Background}

Uterine function is tightly controlled by ovarian steroids [1-5]. The physiological responses to acute estrogen $\left(\mathrm{E}_{2}\right)$ occur in two temporally distinct steps. Early responses appear within the first 2-3 $\mathrm{h}$ after $\mathrm{E}_{2}$ administration while late responses are observed $16-24 \mathrm{~h}$ after $E_{2}$, with each 
step involving activation of distinct sets of genes $[4,5]$. $\mathrm{E}_{2}$ and progesterone $\left(\mathrm{P}_{4}\right)$ exert their effects by binding to specific transcription factor receptors, the estrogen receptors $\alpha(\mathrm{ER} \alpha)$ and $\beta(\mathrm{ER} \beta)$ and the progesterone receptors (PR $A$ and $B$ ), respectively [2-7]. In addition to these classical genotropic effects, $\mathrm{E}_{2}$ and $\mathrm{P}_{4}$ activate extranuclear, nongenomic signaling cascades [8,9]. It is still unclear whether non-genomic effects are mediated by membrane receptors distinct from the nuclear receptors, or additionally involve activation of classical ERs or PRs located outside the nucleus [4-9].

Accumulating evidence suggests that tachykinins (TKs) play a role in the regulation of uterine function $[3,10]$. TKs comprise a family of peptides, which in mammals includes substance P (SP), neurokinin A (NKA) neurokinin B (NKB) and hemokinin-1 (HK) [11-17]. In mice, SP and NKA are encoded by the Tac1 gene (accession number NM_009311), NKB by the Tac2 gene (accession number ENSMUST00000026466) and HK by the Tac4 gene (accession number NM_053093) [10-14]. Their biological effects are mediated by receptors belonging to the family of G protein-coupled receptors. Three different tachykinin receptors are currently recognized, namely the $\mathrm{NK}_{1}$ receptor $\left(\mathrm{NK}_{1} \mathrm{R}\right)$, the $\mathrm{NK}_{2}$ receptor $\left(\mathrm{NK}_{2} \mathrm{R}\right)$ and the $\mathrm{NK}_{3}$ receptor $\left(\mathrm{NK}_{3} \mathrm{R}\right)$ which, in mice, are encoded by the Tacr1(accession number NM_009313), Tacr2 (accession number NM_009314) and Tacr3 (accession number NM_021382) genes, respectively [10-17]. The endogenous tachykinins bind with differing affinities to each of the tachykinin receptors. Thus, the $\mathrm{NK}_{1} \mathrm{R}$ is activated preferentially by SP and $\mathrm{HK}$, the $\mathrm{NK}_{2} \mathrm{R}$ by NKA and the $\mathrm{NK}_{3} \mathrm{R}$ by NKB $[16,17]$.

Tachykinins modulate reproductive function at both central and peripheral levels [18-35]. In the central nervous system, SP, NKA and NKB are expressed in subpopulations of hypothalamic and pituitary neurons where they influence, and are influenced by, gonadotropin and gonadal steroid levels [18-22] and modulate the synthesis and/or secretion of oxytocin [28]. In the reproductive tract, these peptides are expressed in sensory nerves and in non-neuronal cells within the placenta, the ovary, the uterus $[3,10,24-26,29-34]$, the testes and the prostate $[3,36]$. They are also present in other reproductive cells including corpora lutea, oocytes and spermatozoa $[33,35,37]$.

We have previously found that all genes encoding TKs and their receptors are expressed in the mammalian uteri and that their expression and function vary during the ovarian cycle, throughout pregnancy and with age, $[3,10,29,30,38,39]$. In late pregnant and non-pregnant women, in rats, and in late pregnant mice, TKs induce myometrial contractions that are mediated mainly by the
$\mathrm{NK}_{2} \mathrm{R}$ with minor participation of $\mathrm{NK}_{1}$ and $\mathrm{NK}_{3}$ receptors $[10,29,30,39]$. In contrast, in non-pregnant mice, the predominant receptor mediating myometrial contractions is the $\mathrm{NK}_{1} \mathrm{R}$, with $\mathrm{NK}_{2} \mathrm{R}$ playing a minor role $[10,29,39]$. The reasons for this difference between species remain unclear. Indeed, little is known about the physiological mechanisms that regulate the expression of TKs and their receptors in mouse uterus and in particular the influence of ovarian steroids upon their expression.

In this study, we have analyzed the direct effects of the ovarian steroids $\mathrm{E}_{2}$ and $\mathrm{P}_{4}$ on the expression of Tac1, Tac2, Tac4, Tacr1, Tacr2 and Tacr3 in uteri from ovariectomized mice. In addition, we have investigated the effects of the selective agonist of the estrogen receptor $\alpha(E R \alpha)$ propylpyrazole triol (PPT) $[7,40]$, and the selective agonist of the estrogen receptor $\beta$ (ER $\beta$ ) diarylpropionitrile (DPN) [7], in order to define the roles played by ER $\alpha$ and ER $\beta$ in the regulation of TK and TK receptor gene expression. We have also analyzed the effects of estren, a selective activator of non-genomic $\mathrm{E}_{2}$ signaling pathways [8]. Because $\mathrm{E}_{2}$ induced changes in gene expression occur as early or late responses $[4,5]$, animals were treated with $\mathrm{E}_{2}$, PPT, DPN or estren for either 3 or $24 \mathrm{~h}$.

\section{Methods \\ Animals and treatments}

Ethical approval for this study was obtained from Consejo Superior de Investigaciones Científicas (Spain). Virgin female Swiss mice (7-9 weeks, 20-25 g) were purchased from Charles River Laboratories (Barcelona, Spain), housed at $22^{\circ} \mathrm{C}$ under controlled lighting (12:12-h light/ dark cycle) and provided with food and water ad libitum. Animals were bilaterally ovariectomized under avertin anesthesia $(250 \mathrm{mg} / \mathrm{Kg}$, i.p.). Fifteen days later, they were left untreated (control, untreated mice) or treated s.c. with a) $E_{2}(17 \beta$-estradiol benzoate, Sigma, $1 \mu \mathrm{g}$ /mouse); b) the selective ER $\alpha$ agonist propylpyrazole triol (PPT, Tocris, Ellisville, MO, $75 \mu \mathrm{g} /$ mouse); c) the selective ER $\beta$ agonist diarylpropionitrile (DPN, Tocris, $100 \mu \mathrm{g} /$ mouse); d) estren (Steraloids Newport, RI, $300 \mu \mathrm{g} /$ mouse) or e) the same volume of vehicle (olive oil, $100 \mu \mathrm{l}$ ) (control, vehicle-treated mice). In all cases, uteri were collected 3 and 24 $\mathrm{h}$ after the injection. In a second set of experiments, mice were treated with a) $\mathrm{P}_{4}$ (Sigma, $2 \mathrm{mg} /$ mouse per day for 2 days) or its vehicle, and uteri collected $24 \mathrm{~h}$ after the last injection; b) a single injection of $\mathrm{E}_{2}(1 \mu \mathrm{g} /$ mouse $)$ or its vehicle, followed $24 \mathrm{~h}$ later by $\mathrm{P}_{4}(2 \mathrm{mg} /$ mouse per day for 2 days) or its vehicle and uteri collected $24 \mathrm{~h}$ after the last injection; c) a single injection of $\mathrm{E}_{2}(1 \mu \mathrm{g} /$ mouse $)$ or its vehicle and uteri collected $72 \mathrm{~h}$ after treatment. The pharmacological doses of steroid receptor ligands used in the present experiments were based on previously published studies $[2,4-8,39]$. 


\section{Real-time RT-PCR}

Uterine samples were rapidly immersed in RNAlater (Ambion, Huntingdon, UK) and stored at $-80^{\circ} \mathrm{C}$ until use. Total RNA isolation and cDNA synthesis were carried out as previously described [29]. The cDNA samples were amplified by PCR using specific oligonucleotide primer pairs (Table 1) designed with the software Primer 3 and purchased from Sigma-Genosys (Cambridge, UK) [29]. A specific probe $\left(\mathrm{n}^{\circ} 88\right.$, Home probe Library, Exiqon, Vedbaek, Denmark), chosen with the program Probefinder assay design (Exiqon), was used to detect the Tac1 transcript ( $88 \mathrm{bp}$ ) since this gene was present in faint amounts in uteri from pregnant and non-pregnant mice [29]. With this approach, we found that Tac1 mRNA levels were 4.5and 3.0-fold higher in untreated ovariectomized mice, than in estrus and diestrus virgin mice, respectively (unpublished observations). The specific primer pair shown in Table 1 was employed in subsequent experiments for Tac1 detection. Table 1 also shows the primers used to amplify $\beta$-actin $(A c t b)$, protein phosphatase 1 catalytic subunit beta-isoform $(P p p 1 c b)$, glyceraldehyde-3phosphate-dehydrogenase (Gapdh) and polymerase (RNA) II (DNA directed) polypeptide A (Polr2a), which were chosen as housekeeping genes for normalizing the PCR data on the basis of previous studies in the mouse and rat uterus $[29,36,37]$.

Real-time quantitative PCR was performed on a Bio-Rad iCycler iQ real-time detection apparatus (Bio-Rad Laboratories, Hercules, CA) using a FastStart SYBR Green Master (Roche Diagnostics GmbH, Manheim, Germany). The parameters of PCR amplification were: 10 sec at $94^{\circ} \mathrm{C}, 20$ sec at $60^{\circ} \mathrm{C}$ and 30 seconds at $72^{\circ} \mathrm{C}$, for 45 cycles. The identity of each product was established by DNA sequence analysis [29] and the specificity of PCR reactions was confirmed by melting curve analysis of the products and by size verification of the amplicon in a conventional agarose gel.

Real-time PCR data were expressed as the fold change of the target gene expression relative to the geometric mean (g.m.) mRNA expression of the housekeeping genes in each sample, as described by Vandesompele et al. [41]. The fold change in gene expression was calculated by the formula: $2^{-\Delta \Delta C_{T}}$, where $C_{T}$ is the threshold cycle, calculated by the iCycler software, $\Delta \mathrm{C}_{\mathrm{T}}=\left(\mathrm{C}_{\mathrm{T}}\right.$ target gene $\mathrm{C}_{\mathrm{T}}$ g.m.reference genes $)$ and $\Delta \Delta \mathrm{C}_{\mathrm{T}}=\left(\Delta \mathrm{C}_{\mathrm{T}}\right.$ test sample $-\Delta \mathrm{C}_{\mathrm{T}}$ control sample). A pool of uterine cDNAs from untreated, ovariectomized mice, was used as a control sample throughout the study and the ratio of the target gene mRNA/geometric mean of the four reference genes mRNA in this control sample was designated as 1 . Each assay was performed in triplicate and negative controls were run for every assay.

\section{Data analysis}

All values are expressed as the mean \pm S.E.M; $n$ represents the number of mice used. Statistical procedures included one-way ANOVA followed by Dunnett's test for multiple

Table I: Nucleotide sequence of the specific primers used in PCR amplifications.

\begin{tabular}{|c|c|c|c|}
\hline Gene & Primers & Sense & Product Size \\
\hline \multirow[t]{2}{*}{ Tacl } & 5'-GGCCAAGGAGAGCAAAGA-3' & $\mathrm{F}$ & $88 \mathrm{bp}$ \\
\hline & 5'-CGAGGATTTTCATGTTCGATT-3' & $\mathrm{R}$ & \\
\hline \multirow[t]{2}{*}{ Tac2 } & 5'-TCTGGAAGGATTGCTGAAAGTG-3' & $\mathrm{F}$ & 302 bp \\
\hline & 5'-GTAGGGAAGGGAGCCAACAG-3' & $\mathrm{R}$ & \\
\hline \multirow[t]{2}{*}{ Tac4 } & 5'-GTAGCTTCCTCAGCCATGCAG-3 & $\mathrm{F}$ & $186 \mathrm{bp}$ \\
\hline & 5'-CCGCCCCCAAATACAATACA-3' & $\mathrm{R}$ & \\
\hline \multirow[t]{2}{*}{ Tacrl } & 5'-GCCAGAACATCCCAACAGG-3' & $\mathrm{F}$ & 223 bp \\
\hline & 5'-GGCGAAGGTACACACAACCA-3' & $\mathrm{R}$ & \\
\hline \multirow[t]{2}{*}{ Tacr2 } & 5'-TGGTACTGGTGGTGGTGACATT-3' & $\mathrm{F}$ & $25 \mathrm{l} \mathrm{bp}$ \\
\hline & 5'-CCTGTCTTCCTCGGTTGGTG-3' & $\mathrm{R}$ & \\
\hline \multirow[t]{2}{*}{ Tacr3 } & 5'-CCAACTACTGCCGCTTCCA-3' & $\mathrm{F}$ & 272 bp \\
\hline & 5'-GAAATGTTGCTTGGGACCTTCT-3' & $\mathrm{R}$ & \\
\hline \multirow[t]{2}{*}{ Actb } & 5'-TCCCTGGAGAAGAGCTACGA-3' & $\mathrm{F}$ & $362 \mathrm{bp}$ \\
\hline & 5'-ATCTGCTGGAAGGTGGACAG-3' & $\mathrm{R}$ & \\
\hline \multirow[t]{2}{*}{ Gapdh } & 5'-CAATGCCTCCTGCACCAC-3' & $\mathrm{F}$ & $350 \mathrm{bp}$ \\
\hline & 5'-CCTGCTTCACCACCTTCTTG-3' & $\mathrm{R}$ & \\
\hline \multirow[t]{2}{*}{ Ppp/cb } & 5'-AACCATGAGTGTGCTAGCATCA-3' & $\mathrm{F}$ & 472 bp \\
\hline & 5'-CACCAGCATTGTCAAACTCGCC-3' & $\mathrm{R}$ & \\
\hline \multirow[t]{2}{*}{ Polr2a } & 5'-CGTTTCCATCCTAAGCCCAGT-3' & $\mathrm{F}$ & $260 \mathrm{bp}$ \\
\hline & 5'-ATCTCTGCCCGTGTTTCCAG-3' & $\mathrm{R}$ & \\
\hline
\end{tabular}

Shown are the structures of forward $(F)$ and reverse $(R)$ primers of indicated target genes and the size expected for each PCR-amplified product. Primers for Actb ( $\beta$-actin), Gapdh, Ppplcb and Polr2a, used as housekeeping genes, are also shown. 
comparisons and Student's unpaired $t$ test to compare the means of two groups using GRAPHPAD PRISM 4. Statistical significance was accepted when $P<0.05$.

\section{Results}

The transcripts for Tac1, Tac2, Tac4, Tacr1, Tacr2 and Tacr3 were detected in uteri from ovariectomized mice. In all experiments and with all target genes, mRNA expression values were similar in untreated and vehicle-treated mice (Fig. 1, Fig. 2, Fig. 3 and Fig. 4).

\section{Effects on tachykinin gene expression}

Tac1 expression was increased 3-fold in uterine cDNA from mice treated with $\mathrm{E}_{2}$ for $3 \mathrm{~h}$, compared with vehicletreated ( $3 \mathrm{~h}$ ) mice (Fig. 1A). PPT, DPN and estren also increased the Tac1 transcript $3 \mathrm{~h}$ after their administration (Fig. 1A). At $24 \mathrm{~h}, \mathrm{E}_{2}$ decreased 7-fold the expression of Tac1 compared to the respective vehicle controls (Fig. 1A). Treatment with PPT for $24 \mathrm{~h}$ caused a 5-fold decrease in Tac1 mRNA while DNP and estren had no significant effects (Fig 1A). Tac1 mRNA levels remained low in mice after $72 \mathrm{~h}$ treatment with $\mathrm{E}_{2}$ (Fig. 2A). $\mathrm{P}_{4}$ was without effect and did not influence the $\mathrm{E}_{2}$-induced decrease in Tac1 expression (Fig. 2A).

Treatment with $\mathrm{E}_{2}$ for 3 or $24 \mathrm{~h}$ caused large decreases in Tac2 expression, compared with vehicle-treated mice (Fig. 1B). The decrease was still significant at $72 \mathrm{~h}(\mathrm{P}<0.05$, see Fig. 2B). PPT decreased Tac2 mRNA after 3 and 24 h treatment, while neither DPN nor estren had significant effects ( $\mathrm{P}>0.05$, Fig. 2B). Tac2 mRNA was increased 3-fold in mice treated with $\mathrm{P}_{4}$ (Fig. $2 \mathrm{~B}$ ); neither this increase nor the $\mathrm{E}_{2}$-induced decrease were seen in mice treated with both $\mathrm{E}_{2}$ and $\mathrm{P}_{4}$ (Fig. 2B).

Tac4 mRNA levels were decreased 3-fold in mice treated with $\mathrm{E}_{2}$ for $24 \mathrm{~h}$, compared with uteri from corresponding vehicle-treated mice. As shown in Figs. $1 \mathrm{C}$ and 2C, none of the other treatments modified Tac4 expression.

\section{Effects on tachykinin receptor gene expression}

Tacr 1 expression was increased in mice treated for $3 \mathrm{~h}$ with $\mathrm{E}_{2}$ or PPT (Fig. 3A). After treatment with $\mathrm{E}_{2}$ or PPT for 24 $\mathrm{h}$, the mRNA levels were similar to those observed in control, vehicle-treated mice. DPN and estren had no effects either at 3 or $24 \mathrm{~h}$ (Fig. $3 \mathrm{~A}) . \mathrm{P}_{4}$, alone or in combination with $\mathrm{E}_{2}$, was without effect on Tacr1 levels (Fig. 4A).

Compared with uteri from control, vehicle-treated mice, $\mathrm{E}_{2}$ and $\mathrm{P}_{4}$ (alone or in combination), PPT, DPN and estren did not cause significant alterations in Tacr 2 mRNA levels ( $\mathrm{P}>0.05$, Figs. 3B and 4B).

Tacr3 expression was decreased in mice treated with $\mathrm{E}_{2}$ for 3 or $24 \mathrm{~h}$ and in mice treated with PPT for $24 \mathrm{~h}$, compared with vehicle-treated mice (Fig. 3C). DPN and estren had no effect (Fig. 3C). Tacr3 mRNA levels remained low in uteri from mice treated with $\mathrm{E}_{2}$ for $72 \mathrm{~h}$ (Fig. 4C). $\mathrm{P}_{4}$ did not modify Tacr3 expression and did not influence the $\mathrm{E}_{2}$ induced decrease in the expression of Tacr3 (Fig. 4C).

\section{Discussion}

The present study has shown that ovarian steroids tightly and differentially regulate the expression of tachykinin and tachykinin receptor genes in the mouse uteri. Since the uterus is often considered a model to investigate the effects of steroid hormones on gene transcription, this study represents the first analysis of the regulatory effects of $\mathrm{E}_{2}$ and $\mathrm{P}_{4}$ on the whole tachykinin family.

Tac1 mRNA and the tachykinin peptides encoded by this gene, predominantly SP and NKA, are widely expressed in neuronal and non-neuronal cells at both central and peripheral levels $[3,10,20-22,26,29,32]$. Several workers have investigated the effects of ovarian steroids on the expression of this gene and its protein products in the CNS, particularly in the hypothalamic-pituitary axis [18,20-22,32], often with conflicting results. Our findings show that Tac1 was regulated by $\mathrm{E}_{2}$ in a complex and timedependent manner, with both stimulatory and inhibitory effects. The higher expression of Tac1 in ovariectomized animals, compared to non-ovariectomized mice [29], together with the observation that 24-72 h treatment with $\mathrm{E}_{2}$ causes a strong and long-lasting down-regulation of the Tac1 transcript clearly points to the importance of Tac1 regulation by estrogen. In contrast to $\mathrm{E}_{2}, \mathrm{P}_{4}$ had no effect on Tac1 expression nor did it influence the $\mathrm{E}_{2}$-induced decrease.

In the mouse uterus there is a predominance of $E R \alpha$, while ER $\beta$ modulates some of its effects [4-6]. In our study, the $\mathrm{E}_{2}$ effect was mimicked by PPT, a highly selective agonist of ER $\alpha$ devoid of activity on $\operatorname{ER} \beta[7,40]$. In contrast DPN, a highly selective agonist of ER $\beta$ [7], or estren, a purported activator of non-genomic $E_{2}$ signaling [8], were without effect. It thus seems likely that nuclear $\mathrm{ER} \alpha$ mediates the inhibitory effect of $\mathrm{E}_{2}$ (after $24 \mathrm{~h}$ ) on Tac1 expression.

Early physiological responses of the mouse uterus to acute $\mathrm{E}_{2}$ appear within the first 2-3 $\mathrm{h}$ while late responses are observed 16-24 $\mathrm{h}$ after $\mathrm{E}_{2}[4,5]$. Consistent with these findings, 3 h treatment with $\mathrm{E}_{2}$ caused an increase in Tac1 mRNA levels. This early response was also observed in animals treated with PPT, DPN or estren. These findings suggest that early stimulation of Tac1 is mediated by both genomic and non-genomic $\mathrm{E}_{2}$ pathways.

The $\mathrm{NK}_{1} \mathrm{R}$ is the preferred receptor for SP, while NKA can also act as a potent agonist on $\mathrm{NK}_{1} \mathrm{R}$ [13-17]. Therefore, it 

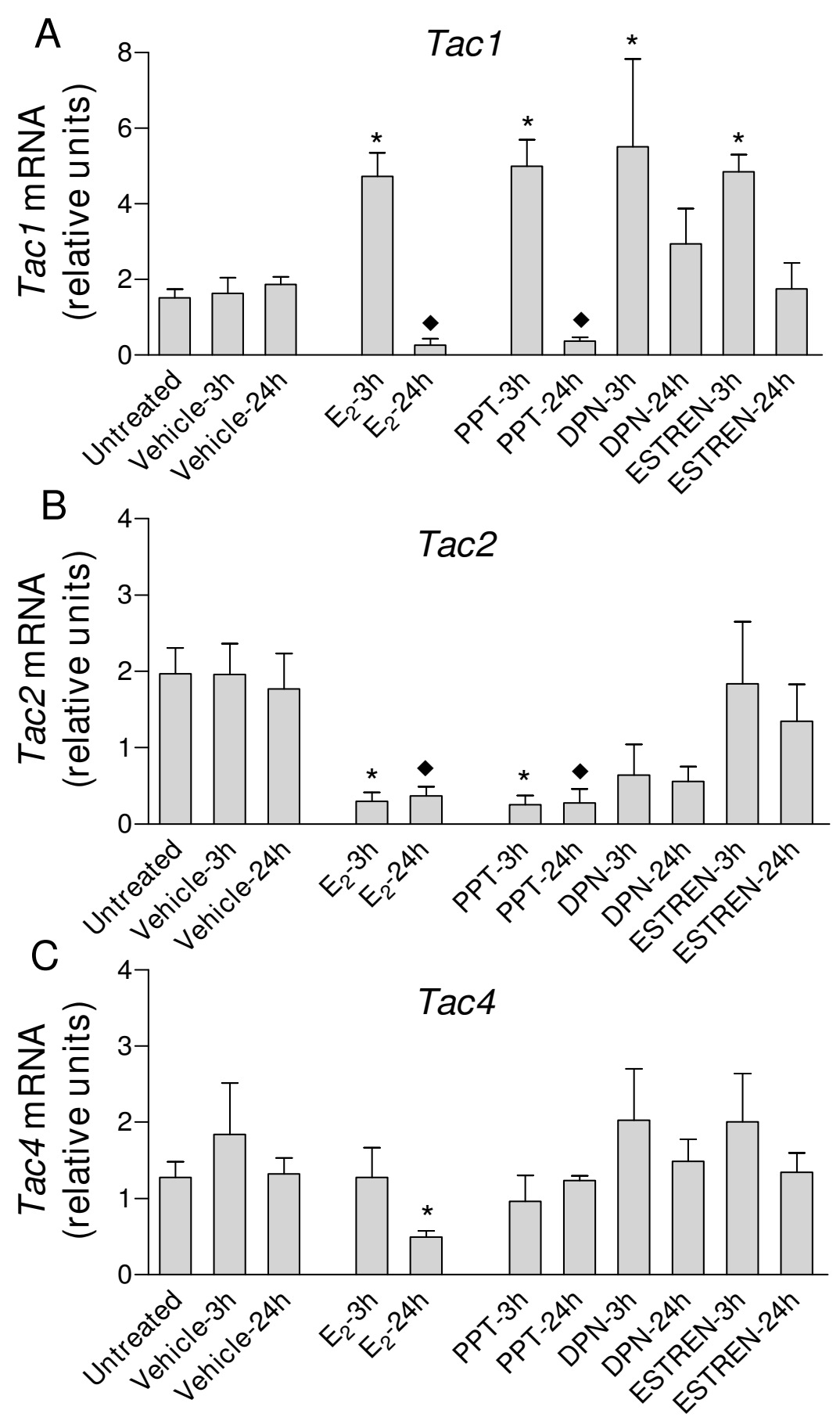

Figure I

Real-time quantitative PCR analysis of A) Tacl; B) Tac2 and C) Tac4 expression in uterine cDNA from mice treated with $E_{2}$, propylpyrazole triol (PPT), diarylpropionitrile (DPN)or estren. Uteri were collected from ovariectomized mice untreated (control) or treated for 3 or $24 \mathrm{~h}$ with $\mathrm{E}_{2}(\mathrm{I} \mu \mathrm{g} / \mathrm{mouse})$ PPT (75 $\left.\mu \mathrm{g} / \mathrm{mouse}\right) \mathrm{DPN}$ (I00 $\left.\mu \mathrm{g} / \mathrm{mouse}\right)$ estren $(300 \mu \mathrm{g} / \mathrm{mouse})$ or the corresponding vehicle. Values are expressed as the fold change of each target-gene expression, relative to the geometric mean mRNA expression of 4 housekeeping genes. Each bar represents the mean of uterine cDNA samples from 5-10 different mice, with S.E.M. shown by vertical lines. $* p<0.05$, significant difference versus mRNA levels in uteri from ovariectomized mice treated for $3 \mathrm{~h}$ with vehicle; $\bullet P<0.05$, significant difference versus mRNA levels in uteri from ovariectomized mice treated for $24 \mathrm{~h}$ with vehicle; one-way ANOVA. 

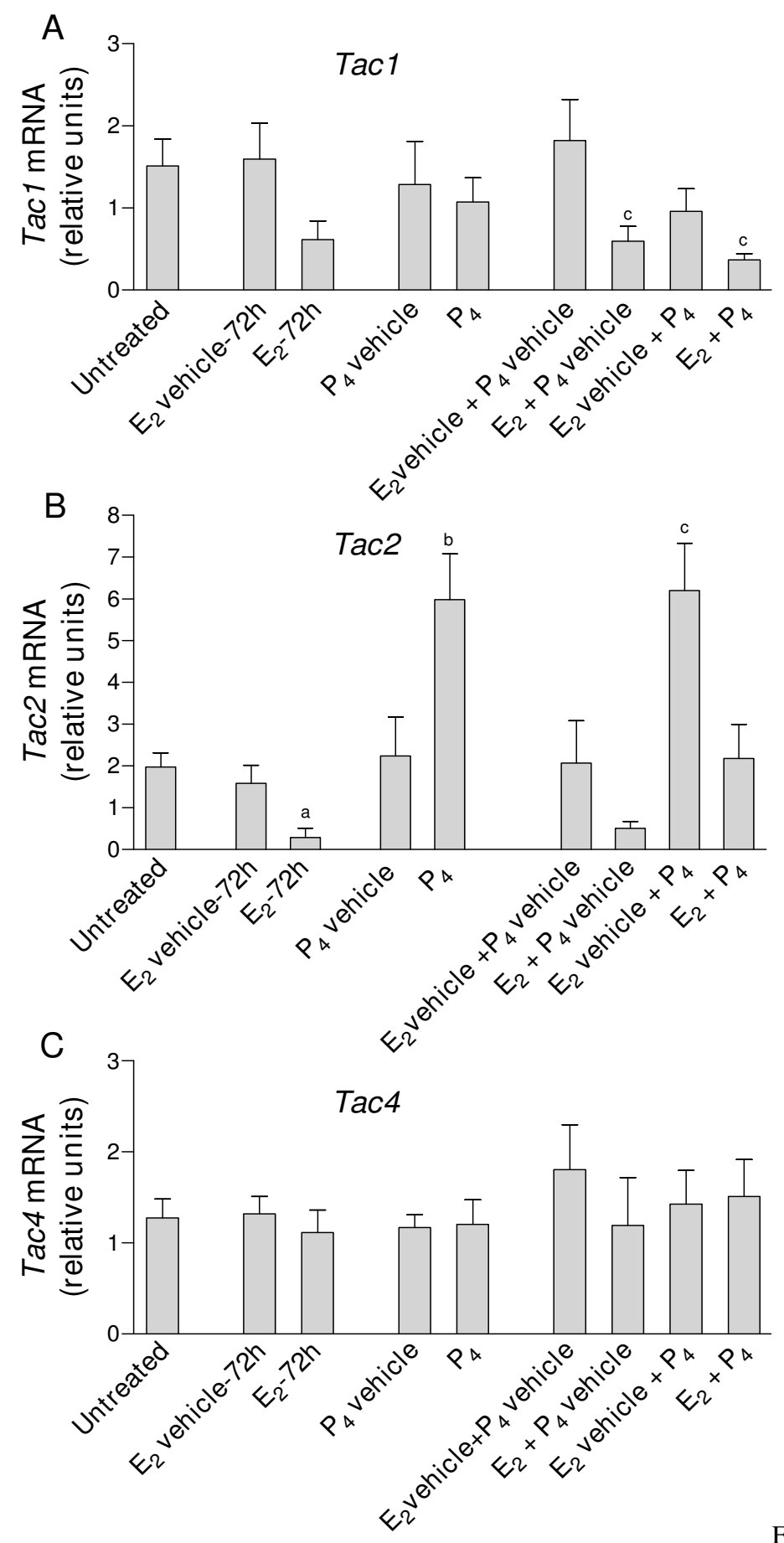

$\mathrm{F}$

Figure 2

Real-time quantitative PCR analysis of A) Tacl; B) Tac2 and C) Tac4 expression in uterine cDNA from mice treated with $\mathbf{E}_{\mathbf{2}}$ and $\mathbf{P}_{\mathbf{4}}$, alone or in combination. Uteri were collected from ovariectomized mice untreated (control) or

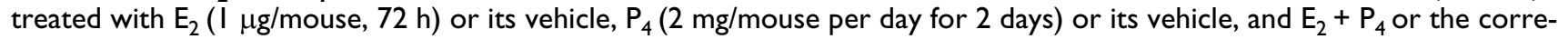
sponding vehicles. Values are expressed as the fold change of each target-gene expression, relative to the geometric mean mRNA expression of 4 housekeeping genes. Each bar represents the mean of uterine cDNA samples from 5-10 different mice, with S.E.M. shown by vertical lines. $\mathrm{P} P<0.05, \mathrm{E}_{2}$ vs. $\mathrm{E}_{2}$ vehicle, unpaired $t$ test; ${ }^{b} P<0.05, \mathrm{P}_{4}$ vs. $\mathrm{P}_{4}$ vehicle, unpaired $t$ test; $c P<$ $0.05, E_{2}+P_{4}, E_{2}+P_{4}$ vehicle and $E_{2}$ vehicle $+P_{4}$ vs. $E_{2}$ vehicle $+P_{4}$ vehicle, one-way ANOVA. 

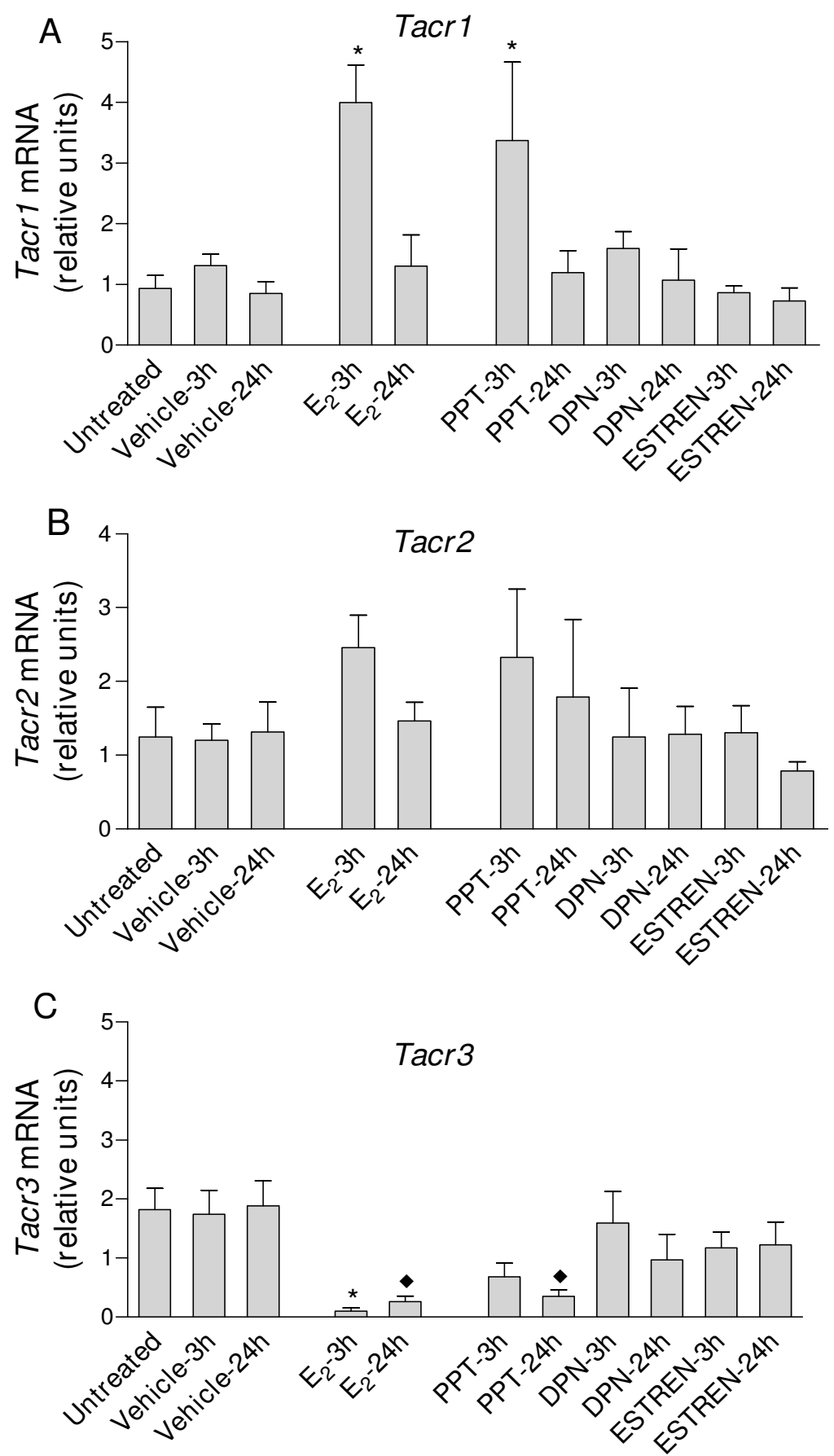

Figure 3

Real-time quantitative PCR analysis of A) TacrI; B) Tacr2 and C) Tacr3 in uterine cDNA from mice treated with $E_{2}$, propylpyrazole triol (PPT), diarylpropionitrile (DPN)or estren. Uteri were collected from ovariectomized mice untreated (control) or treated for 3 or $24 \mathrm{~h}$ with $\mathrm{E}_{2}(\mathrm{I} \mu \mathrm{g} / \mathrm{mouse})$ PPT (75 $\left.\mu \mathrm{g} / \mathrm{mouse}\right)$ DPN (I00 $\left.\mu \mathrm{g} / \mathrm{mouse}\right)$ estren $(300$ $\mu \mathrm{g} / \mathrm{mouse}$ ) or the corresponding vehicle. Values are expressed as the fold change of each target-gene expression relative to the geometric mean mRNA expression of 4 housekeeping genes. Each bar represents the mean of uterine cDNA samples from at least five different mice, with SEM shown by vertical lines. $* P<0.05$, significant difference versus mRNA levels in uteri from ovariectomized mice treated for $3 \mathrm{~h}$ with vehicle; $\bullet P<0.05$, significant difference versus mRNA levels in uteri from ovariectomized mice treated for $24 \mathrm{~h}$ with vehicle; one-way ANOVA. 

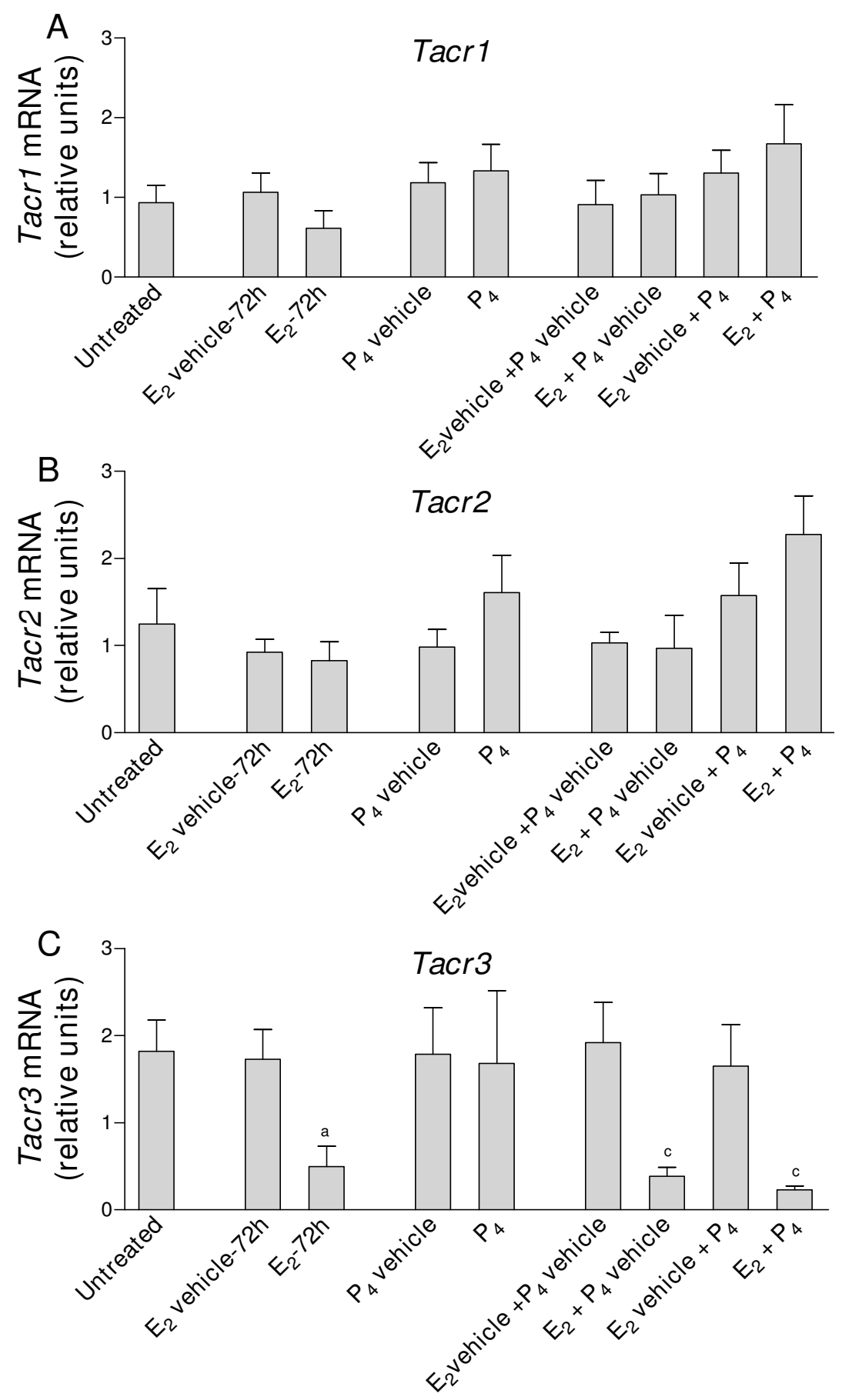

Figure 4

Real-time quantitative PCR analysis of A) Tacrl; B) Tacr2 and C) Tacr3 expression in uterine cDNA from mice treated with $\mathbf{E}_{\mathbf{2}}$ and $\mathbf{P}_{\mathbf{4}}$, alone or in combination. Uteri were collected from ovariectomized mice untreated (control) or treated with $E_{2}(I \mu g / m o u s e, 72 \mathrm{~h})$ or its vehicle, $P_{4}(2 \mathrm{mg} / \mathrm{mouse}$ per day for 2 days $)$ or its vehicle, and $E_{2}+P_{4}$ or the corresponding vehicles. Values are expressed as the fold change of each target-gene expression, relative to the geometric mean mRNA expression of 4 housekeeping genes. Each bar represents the mean of uterine cDNA samples from 5-I0 different mice, with S.E.M. shown by vertical lines. $a P<0.05, E_{2}$ vs. $E_{2}$ vehicle, unpaired $t$ test; $c P<0.05, E_{2}+P_{4}, E_{2}+P_{4}$ vehicle and $E_{2}$ vehicle + $P_{4}$ vs. $E_{2}$ vehicle $+P_{4}$ vehicle, one-way ANOVA. 
was interesting to observe that treatment with $\mathrm{E}_{2}$ for $3 \mathrm{~h}$ caused a parallel increase in both Tac1 and Tacr1 mRNAs. Tacr1 gene expression was also increased in mice treated for $3 \mathrm{~h}$ with PPT revealing the participation of ER $\alpha$. Since tachykinins are potent inflammatory mediators, the present findings may suggest that $\mathrm{SP}(\mathrm{NKA})-\mathrm{NK}_{1} \mathrm{R}$ ligandreceptor pair could play a role in mediating rapid effects of $E_{2}$ in the uterus, such as hyperemia, water imbibition and attraction of immune cells.

Treatment of ovariectomized mice with $\mathrm{E}_{2}, \mathrm{PPT}, \mathrm{DPN}$ or $\mathrm{P}_{4}$ did not decrease $\mathrm{NK}_{1} \mathrm{R}$ gene expression. This finding was unexpected, as we previously found that the transcript for Tacr1 decreases by about 11-fold on day 17 of pregnancy, compared with its expression in uteri from nonpregnant mice [29]. The $\mathrm{NK}_{1} \mathrm{R}$ is regulated by many different mechanisms and it may be that near term, in addition to ovarian steroids, other hormonal, humoral, placental or neural influences may influence its expression.

The $\mathrm{NK}_{2} \mathrm{R}$ is the key tachykinin receptor mediating contractile responses to TKs in the near term uteri from all mammalian species studied $[10,29,30]$. Furthermore, the participation of the $\mathrm{NK}_{2} \mathrm{R}$ in mouse myometrial contractions is higher under conditions of estrogen dominance $[29,39]$. The expression of Tacr2 in uteri from ovariectomized mice was, however, unaffected by treatment with $E_{2}$ or $P_{4}$. This result is consistent with our previous observation that Tacr2 mRNA levels are similar in uteri from pregnant or non-pregnant mice and remain essentially constant during different hormonal stages [29]. Taken together, these findings suggest that, at least in the mouse uterus, the Tacr2 gene is not a direct target for ovarian steroids. The increased response in late pregnancy to agonists that act at the $\mathrm{NK}_{2} \mathrm{R}[29]$ may therefore reflect regulation at a posttranscriptional level.

$\mathrm{NKB}$, together with SP, kisspeptin and dinorphin, is present in a group of hypothalamic neurons that also express estrogen and progesterone receptors $[19,21,42,43]$. NKB is also expressed at all main levels in the female genital tract [10,24-26,29-33] and its excessive secretion from the placenta may cause, in part, some of the symptoms of pre-eclampsia [24,25,31]. Recently, the genome sequence of a non-placental mammal, namely the platypus Ornithorhynchus anatinus, has become available [44] and by phylogenetic analysis, we found that the NKB encoding gene is present (Ensemble entry ENSOANG00000022075). This finding clearly shows that NKB plays additional roles in reproduction, apart from its participation in placental pathophysiology.

$\mathrm{NKB}$ is elevated in the human female hypothalamus after menopause [21]. Additionally, its expression in the rodent brain and in the rat uterus is increased by age and ovariectomy and decreased by $\mathrm{E}_{2}$ treatment $[3,19,38,42]$. These findings and our current observations showing that Tac2 mRNA is strongly repressed in uteri from young ovariectomized mice treated with $\mathrm{E}_{2}$ at all times of treatment indicate that at both central and peripheral levels, NKB over-expression is secondary to ovarian failure $[19,38]$.

Tac2 inhibition was mediated by $\mathrm{ER} \alpha$ because it was observed in mice treated for 3 or $24 \mathrm{~h}$ with PPT, but not with DPN or estren. In addition, our data show, to our knowledge for the first time, that $\mathrm{P}_{4}$ treatment up-regulated Tac2 gene expression in uteri from ovariectomized mice. The mechanism that mediates this $\mathrm{P}_{4}$ effect remains unclear, as in ovariectomized mice, the expression of PRs fall as a consequence of the lack of $E_{2}$ [7]. Although the presence of a basal population of nuclear PRs cannot be excluded, the effects on Tac2 expression may more probably be mediated by activation of membrane-bound $\mathrm{P}_{4}$ receptors distinct from PRs. Several $\mathrm{P}_{4}$ membrane receptor candidates are present in uteri from ovariectomized mice and the expression of some of them is increased by $\mathrm{P}_{4}$ [9]. Up-regulation by $\mathrm{P}_{4}$ would permit a local increase in Tac2 expression following ovulation or in the case of copulation and successful fertilization. These data are in agreement with our previous observations showing that the highest Tac2 levels were found in the mouse uterus around the time of implantation and that these were strongly decreased at late pregnancy [29].

At the peripheral level the role of $\mathrm{NK}_{3} \mathrm{R}$, like that of its preferred ligand $\mathrm{NKB}$, remains poorly understood $[10,31,32,36,45]$. The present data show that $E_{2}$ strongly reduces Tacr3 expression in uteri from ovariectomized mice. The $\mathrm{E}_{2}$-induced responses were mimicked by PPT but not by DPN or estren, providing the first evidence, to our knowledge, that the effects of $\mathrm{E}_{2}$ on this receptor are mediated by ER $\alpha$. The observation that $\mathrm{E}_{2}$ caused a rapid and concomitant down-regulation of Tac2 and Tacr3 expression supports the existence of an important link between $\mathrm{E}_{2}$ and the $\mathrm{NK}_{3} \mathrm{R} / \mathrm{NKB}$ activation pathway [38]. Moreover, the tight regulation of both genes strongly argues for a role of $\mathrm{NKB}$, acting through the $\mathrm{NK}_{3} \mathrm{R}$, in mediating some of the effects of $\mathrm{E}_{2}$ and $\mathrm{P}_{4}$ on uterine function [34,38]. In this context, a recent report has established a correlation between familial hypogonadotropic hypogonadism and mutations in the human genes TAC3 and TACR3 $\cdot[23]$ providing clear evidence for the importance of $\mathrm{NKB}$ and the $\mathrm{NK}_{3} \mathrm{R}$ in reproduction.

The Tac4 gene is expressed in the placenta, the ovary, the uterus, and also in oocytes and blastocyst-stage embryos $[12,29,32,37]$. In the mouse uteri, HK caused myometrial contractions that are mediated by the $\mathrm{NK}_{1} \mathrm{R}$ and are decreased at late pregnancy [39]. Apart from its effects on myometrial contractility, the physiological role of $\mathrm{HK}$ at 
the reproductive level remains poorly understood and its direct regulation by ovarian steroids has not been studied. The present data show that the Tac4 gene is also a target of $\mathrm{E}_{2}$ and suggest that Tac4 expression is down-regulated by $\mathrm{E}_{2}$ surges, as those observed in mammals before ovulation or near labor.

\section{Conclusion}

This study suggests that uterine tachykinins and tachykinin receptors are important targets of ovarian steroids and particularly of $\mathrm{E}_{2}$, acting at ER $\alpha$. The whole tachykinergic system appears involved in the regulation of reproductive functions.

\section{Abbreviations}

SP: substance P; NKA: neurokinin A; NKB: neurokinin B; HK1: hemokinin 1; TK: tachykinin; $\mathrm{NK}_{1} \mathrm{R}$ : $\mathrm{NK}_{1}$ receptor; $\mathrm{NK}_{2} \mathrm{R}$ : $\mathrm{NK}_{2}$ receptor; $\mathrm{NK}_{3} \mathrm{R}$ : $\mathrm{NK}_{3}$ receptor; $\mathrm{E}_{2}$ : estrogen; ER $\alpha$ : estrogen receptor $\alpha$; ER $\beta$ : estrogen receptor $\beta$; PPT: propylpyrazole triol; $\mathrm{DPN}$ : diarylpropionitrile; $\mathrm{P}_{4}$ : progesterone; PR: progesterone receptor; CNS: central nervous system.

\section{Competing interests}

The authors declare that they have no competing interests.

\section{Authors' contributions}

FMP carried out PCR experiments and helped to write the manuscript. COP performed ovariectomy, ovarian steroid treatments and collected uterine samples. EP performed the statistical analysis. JNP and LC wrote the manuscript. FMP and LC designed the study. All authors read and approved the final manuscript.

\section{Acknowledgements}

This work was supported by grants from Ministerio de Educación y Ciencia (BFU2005-04495-C02-0I/BFI and CTQ2007-6I024/BQU) and Junta de Andalucía (FQM26I), Spain.

\section{References}

I. Wray S, Noble K: Sex hormones and excitation-contraction coupling in the uterus: the effects of oestrous and hormones. J Neuroendocrinol 2008, 20:45 I-46I.

2. Ma WG, Song H, Das SK, Paria BC, Dey SK: Estrogen is a critical determinant that specifies the duration of the window of uterine receptivity for implantation. Proc Natl Acad Sci USA 2003, 100:2963-2968.

3. Candenas L, Lecci A, Pinto FM, Patak E, Maggi CA, Pennefather JN: Tachykinins and tachykinin receptors: effects in the genitourinary tract. Life Sci 2005, 76:835-862.

4. Hewitt SC, Deroo BJ, Hansen K, Collins J, Grissom S, Afshari CA, Korach KS: Estrogen receptor-dependent genomic responses in the uterus mirror the biphasic physiological response to estrogen. Mol Endocrinol 2003, I 7:2070-2083.

5. Hewitt SC, Collins J, Grissom S, Hamilton K, Korach KS: Estren behaves as a weak estrogen rather than a nongenomic selective activator in the mouse uterus. Endocrinology 2006, | 47:2203-22|4.

6. Weihua Z, Saji S, Mäkinen S, Cheng G, Jensen EV, Warner M, Gustafsson JA: Estrogen receptor (ER) beta, a modulator of ERalpha in the uterus. Proc Natl Acad Sci USA 2000, 97:5936-594I.
7. Garrido-Gracia JC, Gordon A, Bellido C, Aguilar R, Barranco I, Millan $Y$, de las Mulas JM, Sanchez-Criado JE: The integrated action of estrogen receptor isoforms and sites with progesterone receptor in the gonadotrope modulates LH secretion: evidence from tamoxifen-treated ovariectomized rats. J Endocrinol 2007, I93:107-119.

8. Almeida M, Han L, O'brien CA, Kousteni S, Manolagas SC: Classical genotropic versus kinase-initiated regulation of gene transcription by the estrogen receptor alpha. Endocrinology 2006, 147:1986-1996.

9. Zhang L, Kanda Y, Roberts DJ, Ecker JL, Losel R, Wehling M, Peluso $\mathrm{JJ}$, Pru JK: Expression of progesterone receptor membrane component I and its partner serpine I mRNA binding protein in uterine and placental tissues of the mouse and human. Mol Cell Endocrinol 2008, 287:8I-89.

10. Pennefather JN, Patak E, Pinto FM, Candenas ML: Mammalian tachykinins and uterine smooth muscle: the challenge escalates. Eur J Pharmacol 2004, 500: I5-26.

II. Satake H, Kawada T: Overview of the primary structure, tissuedistribution, and functions of tachykinins and their receptors. Curr Drug Targets 2006, 7:963-974.

12. Page NM: Hemokinins and endokinins. Cell Mol Life Sci 2004, 61:1652-1663.

13. Zhang Y, Berger A, Milne CD, Paige CJ: Tachykinins in the immune system. Curr Drug Targets 2006, 7: I01 I-I020.

14. Almeida TA, Rojo J, Nieto PM, Pinto FM, Hernandez M, Martin JD, Candenas ML: Tachykinins and tachykinin receptors: structure and activity relationships. Curr Med Chem 2004, I I :2045-208I.

15. Gerard NP, Bao L, Xiao-Ping H, Gerard C: Molecular aspects of the tachykinin receptors. Regul Pept 1993, 43:21-35.

16. Burcher E, Mussap CJ, Geraghty DP, McClure-Sharp JM, Watkins DJ: Concepts in characterization of tachykinin receptors. Ann $\mathrm{N}$ Y Acad Sci 1991, 632:123-136.

17. Lecci A, Giuliani S, Tramontana M, Carini F, Maggi CA: Peripheral actions of tachykinins. Neuropeptides 2000, 34:303-3I3.

18. Debeljuk L, Lasaga M: Modulation of the hypothalamo-pituitary-gonadal axis and the pineal gland by neurokinin $A$, neuropeptide $\mathbf{K}$ and neuropeptide gamma. Peptides 1999, 20:285-299.

19. Rance NE: Menopause and the human hypothalamus: Evidence for the role of kisspeptin/neurokinin B neurons in the regulation of estrogen negative feedback. Peptides 2009, 30: III-I22.

20. Brown ER, Harlan RE, Krause JE: Gonadal steroid regulation of substance $P$ (SP) and SP-encoding messenger ribonucleic acids in the rat anterior pituitary and hypothalamus. Endocrinology 1990, 126:330-340.

21. Rance NE, Young WS III: Hypertrophy and increased gene expression of neurons containing neurokinin-B and substance-P messenger ribonucleic acids in the hypothalami of postmenopausal women. Endocrinology I99I, 128:2239-2247.

22. Duval $P$, Lenoir $V$, Kerdelhue $B$ : Ovarian steroid modulation of neurokinin contents in hypothalamus, pituitary, trigeminal nucleus, and cervical spinal cord of the ovariectomized female rat. J Neuroendocrinol 1998, I 0:823-828.

23. Topaloglu AK, Reimann F, Guclu M, Yalin AS, Kotan LD, Porter KM, Serin A, Mungan NO, Cook JR, Ozbek MN, Imamoglu S, Akalin NS, Yuksel B, O'Rahilly S, Semple RK: TAC3 and TACR3 mutations in familial hypogonadotropic hypogonadism reveal a key role for Neurokinin B in the central control of reproduction. Nature Genet 2009, 41:354-358.

24. Page NM, Woods RJ, Gardiner SM, Lomthaisong K, Gladwell RT, Butlin DJ, Manyonda IT, Lowry PJ: Excessive placental secretion of neurokinin $B$ during the third trimester causes pre-eclampsia. Nature 2000, 405:797-800.

25. Lowry PJ: Has the mechanism by which the endocrine placenta scavenges the mother whilst sparing the foetus been unmasked? J Mol Endocrinol 2003, 3 I:34l-347.

26. Debeljuk L: Tachykinins and ovarian function in mammals. Peptides 2006, 27:736-742.

27. Duval $P$, Lenoir $V$, Kerdelhué $B$ : The in vitro effect of substance $P$ on the GnRH-induced LH release depends on the steroidal environment and is reverted by a NKI receptor antagonist (RP 67580) in the cycling female rat. Neuropeptides 1998, 32:97-10I. 
28. Juszczak M, Boczek-Leszczyk E: Oxytocin release from the rat neurohypophysis into the blood: effects of tachykinin NK-I and NK-2 receptors agonists and antagonists. J Physiol Pharmacol 2008, 59:553-562.

29. Patak E, Pinto FM, Story ME, Pintado CO, Fleming A, Page NM, Pennefather JN, Candenas ML: Functional and molecular characterization of tachykinins and tachykinin receptors in the mouse uterus. Biol Reprod 2005, 72: I I25-I I33.

30. Patak E, Candenas ML, Pennefather JN, Ziccone S, Lilley A, Martin JD, Flores C, Mantecon AG, Story ME, Pinto FM: Tachykinins and tachykinin receptors in human uterus. $\mathrm{Br} J$ Pharmacol 2003, 139:523-532.

31. Page NM, Dakour J, Morrish DW: Gene regulation of neurokinin $B$ and its receptor NK3 in late pregnancy and pre-eclampsia. Mol Hum Reprod 2006, I 2:427-433.

32. Ghosh P, Saha SK, Bhattacharya S, Bhattacharya S, Mukherjee S, Roy SS: Tachykinin family genes and their receptors are differentially expressed in the hypothyroid ovary and pituitary. Cell Physiol Biochem 2007, 20:357-368.

33. Brylla E, Aust G, Geyer M, Uckermann O, Löffler S, Spanel-Borowski $\mathrm{K}$ : Coexpression of preprotachykinin $A$ and $B$ transcripts in the bovine corpus luteum and evidence for functional neurokinin receptor activity in luteal endothelial cells and ovarian macrophages. Regul Pept 2005, I 25: 125-I33.

34. Pinto FM, Armesto CP, Magraner J, Trujillo M, Martín JD, Candenas ML: Tachykinin receptor and neutral endopeptidase gene expression in the rat uterus: characterization and regulation in response to ovarian steroid treatment. Endocrinology 1999, I 40:2526-2532.

35. Ravina CG, Seda M, Pinto FM, Orea A, Fernandez-Sanchez M, Pintado $\mathrm{CO}$, Candenas ML: A role for tachykinins in the regulation of human sperm motility. Hum Reprod 2007, 22:1617-1625.

36. Pinto FM, Almeida TA, Hernandez M, Devillier P, Advenier C, Candenas ML: mRNA expression of tachykinins and tachykinin receptors in different human tissues. Eur J Pharmacol 2004, 494:233-239.

37. Pintado CO, Pinto FM, Pennefather JN, Hidalgo A, Baamonde A, Sanchez T, Candenas ML: A role for tachykinins in female mouse and rat reproductive function. Biol Reprod 2003, 69:940-946.

38. Cintado CG, Pinto FM, Devillier P, Merida A, Candenas ML: Increase in neurokinin $B$ expression and in tachykinin NK(3) receptormediated response and expression in the rat uterus with age. J Pharmacol Exp Ther 200I, 299:934-938.

39. Patak E, Pennefather IN, Gozali M, Candenas L, Kerr K, Exintaris B, Ziccone S, Potteck H, Chetty N, Page NM, Pinto F: Functional characterisation of hemokinin- $I$ in mouse uterus. Eur J Pharmacol 2008, 60 I: I 48-153.

40. Stauffer SR, Coletta CJ, Tedesco R, Nishiguchi G, Carlson K, Sun J, Katzenellenbogen BS, Katzenellenbogen JA: Pyrazole ligands: structure-affinity/activity relationships and estrogen receptor- $\alpha$-selective agonists. J Med Chem 2000, 43:4934-4947.

41. Vandesompele J, De Preter K, Pattyn F, Poppe B, Van Roy N, De Paepe A, Speleman F: Accurate normalization of real-time quantitative RT-PCR data by geometric averaging of multiple internal control genes. Genome Biol 2002, I8: I-I I.

42. Dellovade TL, Merchenthaler I: Estrogen regulation of neurokinin B gene expression in the mouse arcuate nucleus is mediated by estrogen receptor alpha. Endocrinology 2004 145:736-742.

43. Navarro VM, Castellano JM, Fernandez-Fernandez R, Barreiro ML, Roa J, Sanchez-Criado JE, Aguilar E, Dieguez C, Pinilla L, Tena-Sempere $M$ : Developmental and hormonally regulated messenger ribonucleic acid expression of KiSS-I and its putative receptor, GPR54, in rat hypothalamus and potent luteinizing hormone-releasing activity of KiSS-I peptide. Endocrinology 2004, 145:4565-4574.

44. Warren WC, Hillier LW, Marshall Graves JA, Birney E, Ponting CP, Grützner F, Belov K, Miller W, Clarke L, Chinwalla AT, Yang SP, Heger A, Locke DP, Miethke P, Waters PD, Veyrunes F, Fulton L, Fulton B, Graves T, Wallis J, Puente XS, López-Otín C, Ordóñez GR, Eichler EE, Chen L, Cheng Z, Deakin JE, Alsop A, Thompson K, Kirby $P$, Papenfuss AT, Wakefield MJ, Olender T, Lancet D, Huttley GA, Smit AF, Pask A, Temple-Smith P, Batzer MA, Walker JA, Konkel MK, Harris RS, Whittington CM, Wong ES, Gemmell NJ, Buschiazzo E, Vargas Jentzsch IM, Merkel A, Schmitz J, Zemann A, Churakov G,
Kriegs JO, Brosius J, Murchison EP, Sachidanandam R, Smith C, Hannon G], Tsend-Ayush E, McMillan D, Attenborough R, Rens W, Ferguson-Smith M, Lefèvre CM, Sharp JA, Nicholas KR, Ray DA, Kube M, Reinhardt R, Pringle TH, Taylor J, Jones RC, Nixon B, Dacheux JL, Niwa H, Sekita Y, Huang X, Stark A, Kheradpour P, Kellis M, Flicek P, Chen Y, Webber C, Hardison R, Nelson J, Hallsworth-Pepin K, Delehaunty K, Markovic C, Minx P, Feng Y, Kremitzki C, Mitreva M, Glasscock J, Wylie T, Wohldmann P, Thiru P, Nhan MN, Pohl CS, Smith SM, Hou S, Nefedov M, de Jong PJ, Renfree MB, Mardis ER, Wilson RK: Genome analysis of the platypus reveals unique signatures of evolution. Nature 2008, 453:175-184.

45. Spooren W, Riemer C, Meltzer H: Opinion: NK3 receptor antagonists: the next generation of antipsychotics? Nat Rev Drug Discov 2005, 4:967-975.
Publish with BioMed Central and every scientist can read your work free of charge

"BioMed Central will be the most significant development for disseminating the results of biomedical research in our lifetime. "

Sir Paul Nurse, Cancer Research UK

Your research papers will be:

- available free of charge to the entire biomedical community

- peer reviewed and published immediately upon acceptance

- cited in PubMed and archived on PubMed Central

- yours - you keep the copyright

Submit your manuscript here:

http://www.biomedcentral.com/info/publishing_adv.asp
BioMedcentral 